Faculty of Design

2010

\title{
Beyond the document: Living institutions of US National Design Policy
}

Tunstall, Elizabeth (Dori) and Jones, Casey

Suggested citation:

Tunstall, Elizabeth (Dori) and Jones, Casey (2010) Beyond the document: Living institutions of US National Design Policy. Design Management Review, 21 (4). pp. 16-22. ISSN 15570614 Available at http://openresearch.ocadu.ca/id/eprint/1279/

Open Research is a publicly accessible, curated repository for the preservation and dissemination of scholarly and creative output of the OCAD University community. Material in Open Research is open access and made available via the consent of the author and/or rights holder on a non-exclusive basis.

The OCAD University Library is committed to accessibility as outlined in the Ontario Human Rights Code and the Accessibility for Ontarians with Disabilities Act (AODA) and is working to improve accessibility of the Open Research Repository collection. If you require an accessible version of a repository item contact us at repository@ocadu.ca. 


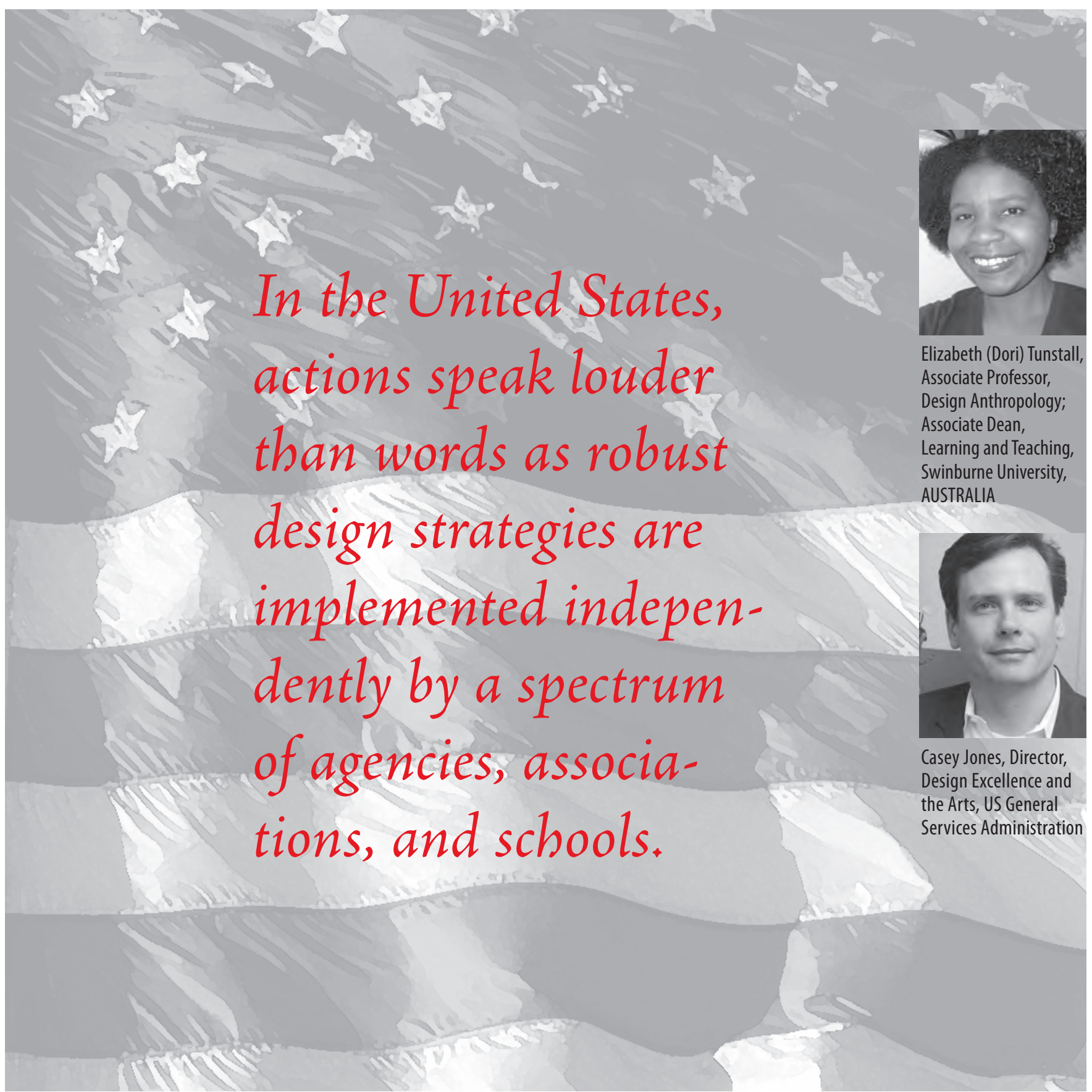




\section{Beyond the Document: Living Institutions of US National Design Policy}

by Elizabeth (Dori) Tunstall and Casey Jones

There is wide consensus among experts that the United States lacks a national design policy. Design policy researcher Gisele Raulik, in her 2007 competitive analysis of national design promotion schemes, lists the United States as one of the countries whose design strategy is at the first level of development (that is, focused on the promotion of design and without government understanding of design's value). ${ }^{1}$ Jaama Hyoene and Hanna Heikkinen, in their 2003 Designum

1. Gisele Raulik, A Comparative Analysis of Strategies for the Promotion of Design in Different National Contexts (Cardiff: University of Wales Institute, 2007).
World Report, state that in the United States there is only “... promotion by national level professional organizations.” In the early'90s, discussions at the Design Management Institute found experts such as Don $\mathrm{Kash}^{3}$ and Thomas Walton ${ }^{4}$ dismissing the advisability and possibility of the United States even having a design policy. But how are

2. Jaana Hyoene and Hanna Heikkinen, Design Policy and Promotion Programs in Selected Countries and Regions (Helsinki, Finland: University of Art and Design in Helsinki, 2003), p. 19.

3. Don Kash, "A National Design Policy: Of Questionable Value and Unlikely," Design Management Journal, vol. 4, no. 3 (1993): pp. 31-35.

4. Thomas Walton, "Options Regarding a US Design Policy," Design Management Journal, vol. 4, no. 3 (1993): pp. 6-9. these experts defining national design policy, and is there something inherent in their definition that excludes the United States?

John Heskett provides the authoritative definition of design policy as "promoting technology and design as a means of gaining economic advantage by enhancing national competitiveness." ${ }^{5}$ Hyoene and Heikkinen position design policy as governmental policies and programs that see design "as a strategic tool for

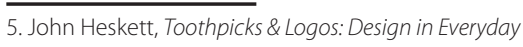
Life (New York: Oxford University Press, 1999), p. 180. 
economic programs and improved competitiveness, as well as its national role in creating jobs and business opportunities." ${ }^{6}$ Gisele Raulik makes it explicit that her focus is on national design program's contributions to economic development. And although their articles predate Heskett's formal definition, both Kash and Walton's understanding of design policy serving economic competitiveness underlies their rejection of it. They argue that in the United States, it is the business community, not the government, that can best promote economic competitiveness. Thus design policy is consistently defined as focused on national economic competitiveness.

The policy analysts here mentioned also define national policy as something that is codified in a formal document. In their report, Hyoene and Heikkinen highlight Denmark, Finland, Ireland, Korea, Norway, and Sweden as having national design policies because they exist in the form of "... official national design policy papers, written in co-operation with the government and various design interest groups..."7 Gisele Raulik describes these nations as having reached "the third level."

Yet the US has had a national design policy in the past. Although it

6. Hyoene and Heikkinen, op. cit., p. 2. They also note the growing importance of social responsibility and welfare as parts of design policy.

7. Hyoene and Heikkinen 2003, p. 19 was not focused on economic competitiveness, the 1970s US Federal Design Improvement Program was a national design policy - at least one that meets the criteria of an official policy document representing a government's valuing of design.

\section{The US Federal Design Improvement Program}

In May 1971, President

Richard Nixon sent a memo to the heads of all the US federal departments and agencies with the mandate to consider how the arts can "contribute to what we in government are seeking to accomplish." 8 Based on the survey of department and agency heads, National Endowment for the Arts Chairman Nancy Hanks responded with the Federal Design Improvement Program, ${ }^{9}$ which consisted of four components: (1) the Federal Design Assemblies, (2) the Federal Graphics Improvement Program, (3) the Federal Architecture Project, and (4) the Federal Designer Recruiting and Rating Procedures.

The first component was a series of federal design assemblies_-basi-

8. NEA (National Endowment for the Arts). "Setting the Standard: The NEA Initiates the Federal Design Improvement Program." In Highlights in NEA History 2005. Available at: http://www.nea.gov/about/40th/fdip.html. 9. For more on this process, which actually began in 1969, see Donna Binkiewicz, Federalizing the Muse: US Arts Policy and the National Endowment for the Arts 1965-1980 (Chapel Hill, NC: University of North Carolina Press, 2004).

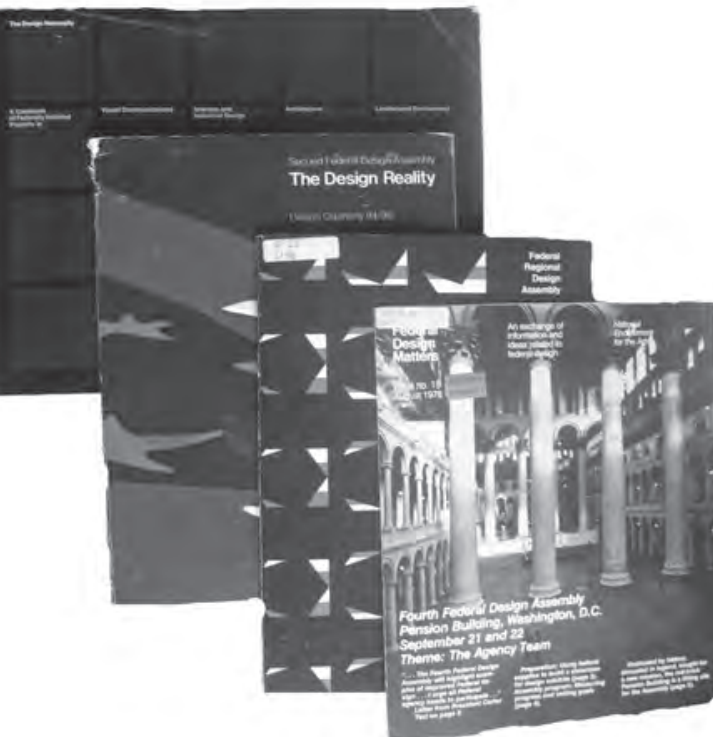

Figure 1. Images of the publications from the four Federal Design Assemblies.

cally a series of exhibitions promoting design. Held in 1972, the first in the series, The Design Necessity, brought together more than 1,000 designers and government administrators to define design's demonstrable "performance in response to human needs." 10 The second assembly, The Design Reality, was held in 1974 with more than 800 participants and continued the efforts to generate "a new understanding and enthusiasm for design excellence in the Federal Government." 11 Two more regional assemblies followed in $1975^{12}$ and in 1978 (Figure 1). ${ }^{13}$

\footnotetext{
10. See Ivan Chermayeff, Richard Saul Wurman, Ralph Caplan, Peter Bradford, and Jane Clark, The Design Necessity: A Casebook of Federally Initiated Projects in Visual Communications, Interiors and Industrial Design, Architecture, and Landscaped Environment (Cambridge, MA: MIT Press, 1973). 11. Mildred Friedman (ed.). "Second Federal Design Assembly: The Design Reality." Design Quarterly 94/95 (1975): pp. 1-76.

12. See Federal Regional Design Assembly: Western States. Denver, CO: National Endowment for the Arts, 1975. 13. See Simpson Lawson, "Assembly to Focus on the Agency Team." Federal Design Matters, no. 15 (1978): pp. 1-6.
} 
The second component was the Federal Graphics Improvement Program, an example of setting design standards for quality in government communications. More than $45 \mathrm{fed}$ eral agencies, from the Department of Agriculture to the National Zoo, had their graphics critiqued and redesigned by such prestigious designers as Richard Danne and Bruce Blackburn (Figure 2). ${ }^{14}$ Third came the Federal Architecture Project, which set design standards for governmental architecture and landscape design, including passage of the Public Buildings Cooperative Use Act of 1976 on "barrier-free" federal building accessibility and public use (Figure 3). The fourth component was the Federal Designer Recruiting and Rating Procedures, which sought to increase the quality of designers in the federal government.

Spanning the terms of four US presidents ${ }^{15}$ between 1972 and 1981, the Federal Design Improvement Program was probably one of the most ambitious national design policies ever conceived and implemented. Yet it is not recognized as a national design policy because it fails to fit the model of design policy for economic competitiveness. But that is surely the fault of history. Unlike

14. See Lanni Lattin, "Graphics in Progress," Federal Design Matters, no. 4 (1975): pp. 1-6. 15. President Nixon, President Ford, President Carter and President Reagan.

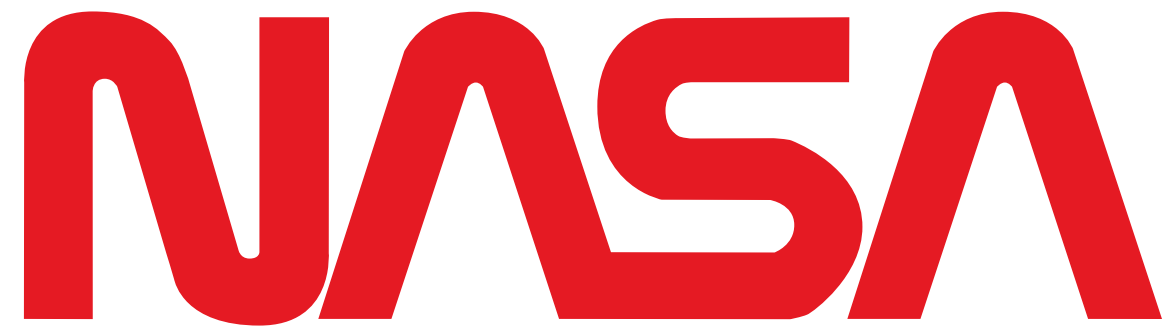

Figure 2. Richard Danne and Bruce Blackburn"s NASA logo (1975-1992), commissioned as part of the Federal Graphics Improvement Program.

the United Kingdom and Japan, which forged their design policies after World War II, the United States emerged economically dominant in the postwar period. A formal design policy document seemed unnecessary, given the way in which the militaryindustrial complex served as the engine for the United States' economic development, innovation, and growth. ${ }^{16}$ Yet with the domestic turbulence of the 1960s, the US did require a national design policy that in its "rejection of visual mediocrity in gov-

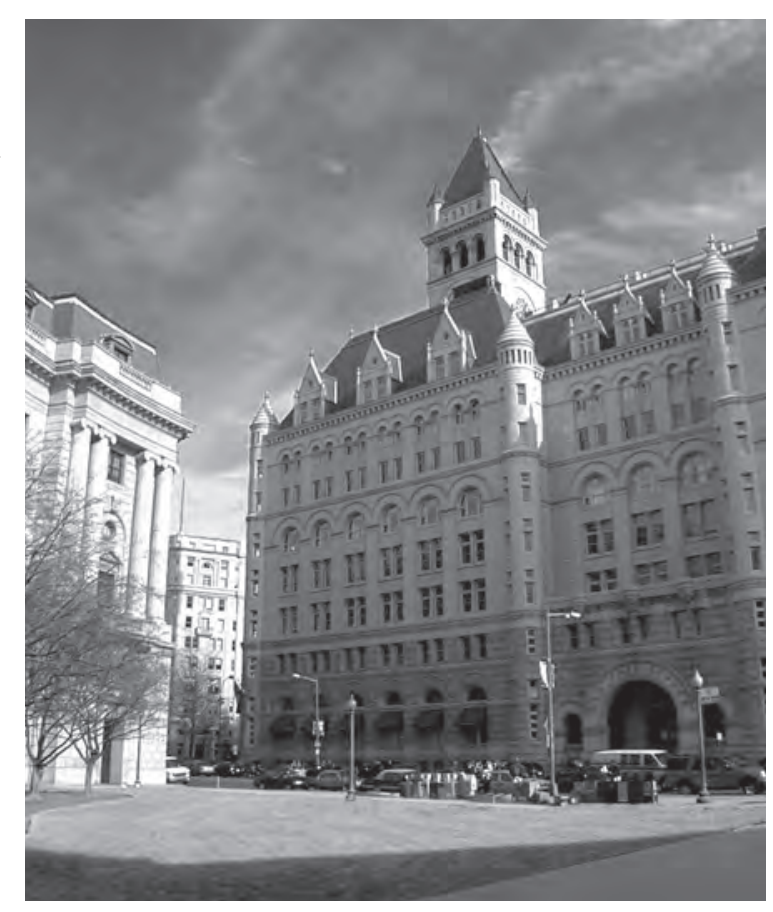

Figure 3. The Old Post Office Building in Washington, DC, was one of the first to be converted to a mixed-use public building by the GSA after 1976.

ernment design standards would also improve the image of the American government in the public eye." ${ }^{17}$ Thus, the country did not craft a design policy for economic competitiveness,

16. For an in-depth discussion of the pervasiveness of the military-industrial complex and its role in US economic competitiveness, see Nick Turse, The Complex: How the Military Invades Everyday Lives (New York City: Henry Holt and Company, 2008).

17. Binkiewicz, op. cit., p. 163. but rather a "design policy for democratic governance." ${ }^{18}$

The Federal Design Improvement Program ended in 1981 with the election of President Ronald Reagan. The demise of the formal

18. For the origin of this concept, see Elizabeth Tunstall, "In Design We Trust: Design, Governmentality, and the Tangibility of Governance." International Associations of Design Research Societies (IADRS) Conference 2007 (Hong Kong, China: School of Design, the Hong Kong Polytechnic University, 2007). 
program was based on a concerted shift by the Reagan Administration to increase private support of the arts and humanities. As a purely government-sponsored program, the Federal Design Improvement Program did not meet the profile of projects that could encourage participation of community foundations or city pairing and sharing. ${ }^{19}$ Yet the goals of the program were not abandoned; rather, they were internalized as a "living institution" within the US General Services Administration (see sidebar).

But what do we mean by a living institution?

\section{The US National Design Policy Initiative}

The bias toward economic competitiveness in the analysis of design policy has created a significant blind spot in relationship to national design policy in the United States. What about the bias toward formal documents? It has implications for the understanding of the current US National Design Policy Initiative, which is based on an idea of design policy as living institution. This idea is tied to American behavioral approaches to political science in the 1950s and 1960s. It directly critiqued

19. See Barnabas McHenry, "Notes on the Presidential Task Force on the Arts and Humanities and President's Committee on the Arts and Humanities," The Annals of the American Academy, no. 471 (Jan. 1984): pp. 107-116.

\section{The GSA as a US Design Policy Living Institution}

ince 1949, the US General Services Administration (GSA) has been responsible for nonmilitary and non-State Department federal architecture through its Public Buildings Service. In 1994, GSA established the Design Excellence program to address the perception that the quality of federal architecture had been in decline. Although independent of the US Federal Design Improvement Program, Design Excellence's DNA derives from earlier efforts to improve the quality of federal design.

Specifically, Design Excellence takes as its mandate the "Guiding Principles for Federal Architecture," a study authored in 1962 by the Ad Hoc Committees on Federal Office Space. The study calls for: (1) producing facilities that reflect the dignity, enterprise, vigor, and stability of the federal government, emphasizing designs that embody the finest contemporary architectural thought; (2) avoiding an official style; and (3) incorporating the work of living American artists in public buildings. In so doing, each building expresses design excellence as part of a larger body of work that represents the best of American design.

To secure top creative talent, the Design Excellence Program has simplified the way GSA selects architects and engineers, and opened opportunities for emerging talent, as well as small, disadvantaged, and women-owned businesses. The program also collaborates with organizations like the American Institute of Architects, the American Society of Landscape Architects, the International Interior Design Association, the Society of Environmental Graphic Designers, and the National Organization of Minority Architects to uphold and promote a shared set of design goals. Through Design Excellence, GSA has engaged many of the finest architects, engineers, designers, and artists working in the United States today, and has brought the agency and the federal government widespread recognition and praise.

formal-legal approaches to governance that saw legislation as the "most striking manifestation of political power." ${ }^{20}$ Note how the definitions

20. Johan P. Olsen, “Organizing European Institutions of Governance: A Prelude to an Institutional Account of Political Integration," Arena Working Paper, no. 00/2 (2000). Available at: http://www.arena.uio.no/publications/wp00_2.htm\#*_opp. of design policy by experts who see it culminating in a policy document echo this formal-legal approach. The living-institutions approach relies upon understanding how "mutually agreed-upon and recognized codes of conduct are the product of "in vivo negotiations" where the culmination 
is in new institutional practices. ${ }^{21}$ In some cases, this describes the policy process after the formal document and now in its implementation. In the case of the US National Design Policy Initiative, it describes how the participants are engaged in all the activities of design policy, without a formal document.

Established in a 2008 Design Policy Summit, the US National Design Policy Initiative's mission is the establishment a governmental plan of action for design in the service of the country's economic competitiveness and democratic governance. ${ }^{22}$ The Initiative's framework of design policy is based on author Tunstall's more than two years of academic research on global national design policies. ${ }^{23}$ She created a broad and

21. See Maarten Hajer, "The Living Institutions of the EU: Analyzing Governance as Performance," Perspectives on European Politics and Society 7, no. 1 (2006): pp. 41-55. 22. See their website at http://www.designpolicy.org. 23. See Elizabeth Tunstall “In Design We Trust: Design, Governmentality, and the Tangibility of Governance." Paper presented at the International Associations of Design Research Societies (IADRS) Conference 2007 (Hong Kong Polytechic, Hong Kong, 2007). In the article, she describes her travels to Europe to look at design policy in the context of the German Marshall Fund; the establishment of the Design Policy YahooGroup, where she met many of the authors of Europe's design policies; and her work as research and then managing director of Design for Democracy during their Election Design project. multileveled framework of design policy under the category of Design Policy for Economic Competitiveness, further divided into Design Promotion and Innovation Policy; and Design Policy for Democratic Governance, further divided into Design Standards and Policy as Designed. Additional subdivisions provide greater detail (see Figure 4).

The redefinition of design policy into this framework sought to ensure the success of the initiative by addressing some of the reasons for the failure of previous ones. Organizers knew that policy-makers rely

\section{Design Policy for Economic Competitiveness}

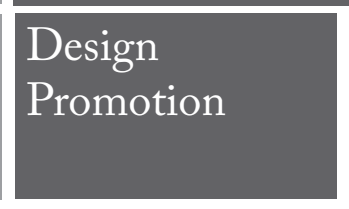

Innovation Policy

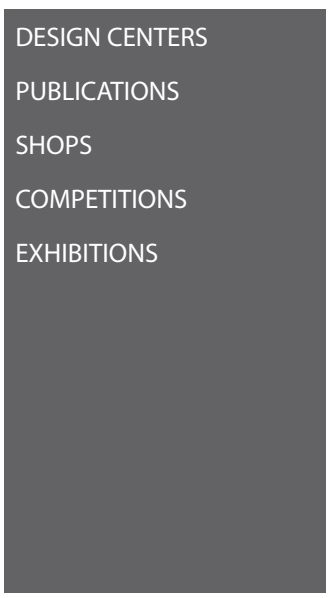

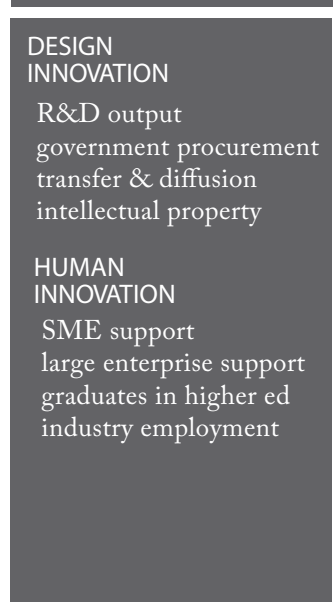

transfer \& diffusion

intellectual property

HUMAN

INNOVATION

graduates in higher ed

industry employment

Design Policy Initiative. 
tions, design education bodies, and the federal government (Figure 5).

Previous discussions were bogged down by arguments on the hypothetical merits of a US national design policy. The map of participants as living institutions of design

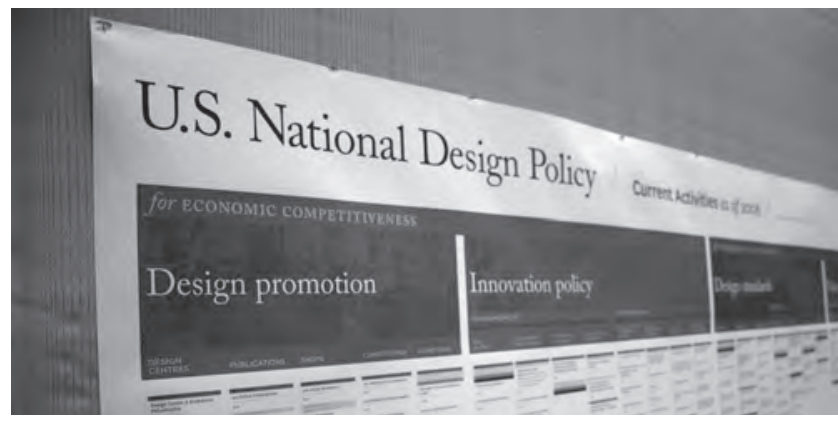

Figure 5. Image of the Current Activities Map from the 2008 National Design Policy Summit. policy enabled the focus of the summit to be on how to optimize and scale nationally their design policy practices. Indeed, the initiative's objective of establishing an American Design Council drew upon the Federal Advisory Committee as the vehicle through which to offer the Federal Government "the advice and assistance of our nation's citizens." ${ }^{25}$

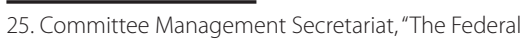
Advisory Committee Act (FACA) Brochure" (Washington, DC: Office of Governmentwide Policy, US General Services Administration, 2010).

\section{Conclusion}

The blind spots created by defining design policy as economic competitiveness resulted in design policy experts missing the significance of the United States' Federal Design Improvement Program as a formal national design policy. The same bias toward formal-legal manifestations of design policy can result in a focus on design policy declarations as opposed to design policy practices. The
US represents an alternative model to both types of design policy. The Federal Design Improvement Program demonstrates the legitimacy of design policy for democratic governance. The US Design Policy Initiative frames an alternative goal for a national design policy - to move beyond the document to design policy as living institutions.

\section{Suggested Reading}

Tunstall, Elizabeth."US National

Design Policy Initiative Summit

Report: November 11-12, 2008."

Washington, DC: US National

Design Policy Initiative 2009.

Available at: http //www.designpolicy.org/files/usnatldesignpoli-

cysummit_report-2.pdf.

Reprint \#10214TUN16

\section{www.ikonographic.com}

Compatible with iOS 4,4, Phone 3G, iPhone 3GS, iPhone 4.

and the 2010 edition of IPod Touch, the norie seith a cameral

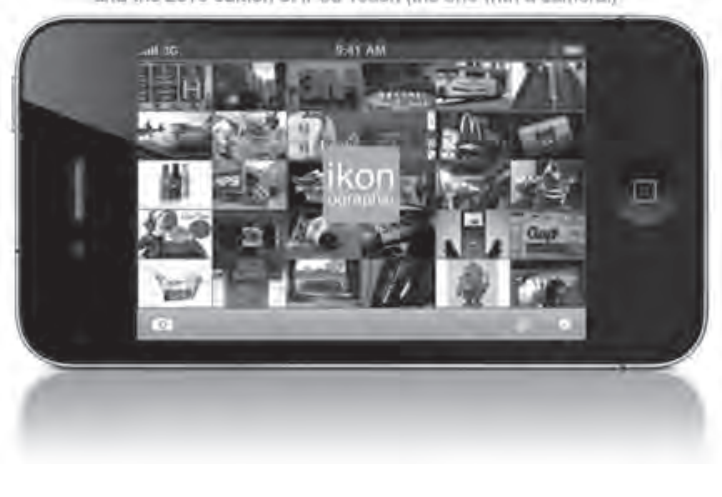

Capture a world of brands."

ikon

ikonographic is a free app for your iPhone* that makes it easy to shoot and tag brand images. Once captured, your images are transmitted to www.ikonographic.com where you, and fellow ikonographers, can collect, search, and comment on brands from around the world. Simple.

Every capture adds to our knowledge of brands "in the wild." Every capture helps us to better understand how brands live and evolve across the planet. Join us!

Gearieri tor the branding oommentity by Lead Brands and The Miahty Ants. 